\title{
Post-prandial lipase, pepsin and acid secretion of a Heidenhain pouch in the rabbit
}

\author{
JP Perret 1, M Daoud-El Baba 1, I Gros 1, M Descroix-Vagne 2
}

\author{
1 Université Claude-Bernard-Lyon I, IUT A, Laboratoire de Physiologie de la Nutrition, \\ 43, bd du 11-Novembre-1918, F 69622 Villeurbanne cedex; \\ 2 INSERM U45, Hôpital É-Herriot, Lyon, France
}

(Received 6 May 1992; accepted 16 March 1993)

\begin{abstract}
Summary - The kinetics of the gastric secretion of lipase, pepsin and acid were studied after a meal in Heidenhain-pouch rabbits. After a $24-\mathrm{h}$ fast, feeding immediately stimulated $(<15 \mathrm{~min}) \mathrm{li}$ pase $(x 4.1)$ and later on pepsin (x 1.8) output which reached respectively 16 and $47 \%$ of the output

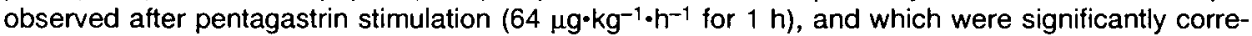
lated. Lipase concentration was enhanced earlier and to a greater degree $(x 7.3)$ than pepsin concentration $(x 2.5)$. No stimulation of high basal acid secretion occurred. It was concluded that: 1) gastric lipase secretion is stimulated by feeding in the rabbit; 2) pepsin secretion is stimulated by feeding. The modalities of the secretion of lipase and pepsin are compatible with the existence of distinct secretory cells; 3 ) acid secretion is not stimulated by feeding. The decrease in acid secretion during the post-prandial phase favors a physiological role for lipase which is altered by low $\mathrm{pH}$. The absence of acid stimulation by feeding in the rabbit, in contrast to other species, requires additional studies on the release of gastrointestinal hormones, namely gastrin, cholecystokinin and somatostatin.
\end{abstract}

gastric lipase secretion / gastric acid secretion / pepsin secretion / feeding / rabbit

Résumé - Sécrétion post-prandiale de lipase, pepsine et acide d'une poche de Heidenhain chez le lapin. Les cinétiques des sécrétions de lipase, pepsine et acide d'une poche de Heidenhain ont été étudiées lors de la prise de nourriture chez le lapin. Après un jeûne de $24 \mathrm{~h}$, le repas stimule immédiatement $(<15 \mathrm{~min})$ les débits de lipase $(x 4,1)$ et de pepsine $(x 1,9)$ qui atteignent alors respectivement 21 et $52 \%$ de celui obtenu lors de la stimulation maximum à la pentagastrine $\left(64 \mu \mathrm{g} \cdot \mathrm{kg}^{-1} \cdot \mathrm{h}^{-1}\right.$ pendant $1 \mathrm{~h}$ ) et sont significativement corrélés. La concentration de lipase augmente davantage que celle de pepsine ( $x 7,2$ vs $\times 2,5)$. Le repas ne stimule pas la sécrétion acide dont la valeur basale est élevée. Nous concluons que l'estomac du lapin sécrète une lipase, dont l'activité est favorisée par l'absence d'hypersécrétion acide post-prandiale; les cinétiques des sécrétions de lipase et de pepsine confirment leur origine cellulaire différente; les caractéristiques de la libération post-prandiale des hormones gastro-intestinales, en particulier gastrine, cholecystokinine et somatostatine, doivent être établies chez le lapin.

lipase gastrique / sécrétion acide gastrique / pepsine / prise de nourriture / lapin 


\section{INTRODUCTION}

Although the activity of preduodenal lipases has been well studied in vitro, their mechanism of secretion is largely unknown. Studies performed in vivo show that the lipolytic activity of gastric contents in adult volunteers is stimulated by central vagal stimulation (Szafran et al, 1971) and pentagastrin (Moreau et al, 1988b; Moreau et al, 1990b; Szafran et al, 1978) but that like secretin, cholecystokinin has no effect (Moreau et al, 1988b). In the newborn, lipolytic activity is found in the stomach only after a meal (Fredrikzon and Hernell, 1977); or it disappears from the gastric mucosa after suckling (Perret and Bacques, 1983). These in vivo results were often obtained without sufficient care in determining the origin and preservation of the lipase (Fredrikzon and Hernell, 1977; Szafran et al, 1971, 1978), and do not demonstrate that gastric lipase is effectively secreted or that it plays a significant physiological role in the digestion of triacylglycerols.

Our study reports for the first time the evolution of the secretions of lipase, acid and pepsin of a Heidenhain pouch after a meal in the rabbit, whose stomach is the richest in lipases amongst all species so far studied (Moreau et al, 1988a). As the pouch is no longer in contact with food, the unbuffered juice has a very low $\mathrm{pH}$ which might alter lipase: pouch perfusion allows the maintenance of a $\mathrm{pH}$ that is compatible with lipase and pepsin stability. The effect of perfusion itself was evaluated on acid and pepsin secretion. The responses were compared to those induced by pentagastrin, which has been shown to be the best lipase stimulant in this species (Perret et al, 1993). In order to quantify the amount of lipase secretion, the lipase content of the gastric mucosa was also determined.

\section{ANIMALS}

French official regulations (decree No 87849,19 October 1987) for the care and use of laboratory animals were followed.

Female New Zealand rabbits were obtained from the Élevage Scientifique des Dombes, Chatillon-sur-Chalaronne, France, and maintained ad libitum on rabbit chow (UAR) and water. When equipped with the Heidenhain pouch, rabbits received water supplemented with $\mathrm{NaCl}(0.10 \%$, wt/vol) and $\mathrm{KCl}(0.02 \%$, wt/vol).

\section{MATERIALS AND METHODS}

Bovine serum albumin (BSA; fraction V, essentially fatty-acid free) and taurodeoxycholic acid sodium salt (TDC) were obtained from Sigma Chemicals. Hemoglobin protease substrate and Folin-Cioccalteu's phenol reagent, came from Merck. Tributyrin puriss was from Fluka, pepsin from Worthington Biochem, Corp NJ, pentobarbital from Sanofi, chlorpromazine (Largactil) and extencillin from Specia, ranitidine (Azantac) from Glaxo and pentagastrin (Peptavlon) from $\mathrm{ICl}$ Pharma.

Titanium cannulae, described by Gregory (1958), were obtained from Down-Bros and Mayer and Phelps Ltd, Surrey, UK. Sterile linen sutures came from Peters and Robert and Carrière, France.

\section{Surgical procedure}

A detailed description of the procedure used in the preparation of the Heidenhain pouch (HP) has been reported by El Baba et al (1991). The pouches were isolated from the fundic part of the greater curvature of the stomach. A Gregory's caninula was inserted in the ventral part of the pouch. A recovery period of 1 month was observed. 


\section{Experimental procedure}

\section{Collection of the gastric secretion}

After a 24-h fast with water available ad libitum and a collar to prevent coecotrophy, rabbits were placed in a harness. The pouch secretion was collected by 2 procedures, with and without pouch perfusion in each animal in a separate set of experiments.

With the first procedure, the pouch was continuously perfused without inducing any pressure with $2.5 \mathrm{ml}$ recirculating solution of $\mathrm{BSA}$ $5 \%(\mathrm{wt} / \mathrm{vol}$ ) in $\mathrm{NaCl} 0.9 \%$ (wt/vol) adjusted to $\mathrm{pH}$ 5.5 at a rate of $2 \mathrm{ml} \cdot \mathrm{min}^{-1}$, with a catheter inserted in the pouch through the cannula (id $=1.9$ $\mathrm{mm}$ ). The perfusate flowed freely from the pouch through the cannula by gravity in a funnel emptying into the vessel where its $\mathrm{pH}$ was continuously adjusted to 5.5 with $\mathrm{NaOH} 0.2 \mathrm{~N}$; the volume of the latter was recorded to provide the acid output per period. The vessel was weighed before and after each 15-min period, the difference giving the amount of gastric juice.

With the second procedure without gastric perfusion, the pouch secretion was directly collected in preweighed tubes.

Three 15-min basal periods were incorporated with 2 preliminary 15 -min periods to equilibrate the system in the perfusion protocol.

The rabbits received $6 \mathrm{~g}$ of their habitual industrial chow over a 15-min period. The test was continued for 5 to 615 -min periods ( 1 to 5 experiments for each of the 6 rabbits in both series).

In separate experiments the rabbits received an intravenous injection of pentagastrin 164 $\mu \mathrm{g} \cdot \mathrm{kg}^{-1} \cdot \mathrm{h}^{-1}$ for $1 \mathrm{~h}$ ).

\section{Analytical procedures}

Acid output was directly assessed by the volume of $\mathrm{NaOH}$ used to maintain the $5.5 \mathrm{pH}$ during each period in the perfusion experiments. In the non-perfusion experiments, acid concentration was determined in $0.1 \mathrm{ml}$ gastric juice from the pouch with $0.1 \mathrm{~N} \mathrm{NaOH}$ by $\mathrm{pHmeter}$ and an autoburet (Radiometer).

Pepsin and lipase concentrations were determined in duplicate the same day on which the experiment was performed.
The measurement of pepsin as described by Anson (1938) was adapted to low volumes. Incubations were carried out for $10 \mathrm{~min}$ at $25^{\circ} \mathrm{C}$ with $0.2 \mathrm{ml}$ hemoglobin substrate and $50 \mu \mathrm{l}$ appropriately diluted perfusate. A blank was made for each dosage by adding trichloracetic acid to the substrate before the incubation. Isolation of the soluble products of hemogiobin proteolysis was assured by 3-min centrifugation at $11000 \mathrm{~g}$ of the trichloracetic precipitate. Quantification of these products was carried out with FolinCioccalteu's phenol reagent. A calibration curve was made with pepsin standards from 12.5 to $150 \mu \mathrm{g} \cdot \mathrm{ml}^{-1}$.

The measurement of lipase was adapted from Gargouri (1986a). Emulsification of $0.7 \mathrm{ml}$ tributyrin in $19.3 \mathrm{ml} \mathrm{NaCl}$ solution $0.9 \%$, BSA $0.01 \%$ and TDC $0.1 \%$ (wt/vol) was carried out by sonication for $8 \mathrm{~min}$ at $25 \mathrm{~W}$ in a $30-\mathrm{ml}$ screw-capped tube dipped in crushed ice. We measured at $37^{\circ} \mathrm{C}$ with the aid of a $\mathrm{pH}$ stat the quantity of butyric acid released at $\mathrm{pH} 5.5$ over a 3 -min period after the addition of $0.1 \mathrm{mi}$ perfusate or gastric extract to $1.5 \mathrm{ml}$ emulsion with continuous magnetic stirring and under nitrogen flow. Neutralization was assured with freshly prepared $0.02 \mathrm{~N} \mathrm{NaOH}$.

Results are expressed in $\mu \mathrm{Eq} \mathrm{H}^{+}$or in $\mathrm{mg}$ pepsin or in units lipase secreted for $15 \mathrm{~min}$. One unit lipase released $1 \mu$ Eq butyric acid in 1 $\min$.

\section{Determination of lipase activity in the gastric mucosa}

The fresh stomach of 5 non-fasted rabbits was excised at the level of the pericardia, the fundus near the greater curvature, ie at the site of the $\mathrm{HP}$, the corpus and the antrum. The mucosa was removed from each sample and weighed, then homogenized in an ice-bath for $20 \mathrm{~s}$ with a motor-driven microhomogenizer. Homogenates were centrifuged for $5 \mathrm{~min}$ at $10000 \mathrm{~g}$ and lipolytic activity measured in the clear supernatant as already described using $0.1 \mathrm{~N} \mathrm{NaOH}$. Protein content was determined by the Lowry procedure (1951).

\section{Stastistical analysis}

Data obtained for each rabbit were averaged before the group data were pooled. The non- 
parametric Wilcoxon test for paired values was used to test the effect of the alimentary stimulus. The non-parametric Mann-Whitney test was chosen to compare the procedure. Correlation coefficients between the acid, pepsin and lipase output were calculated.

\section{RESULTS}

\section{Basal secretion}

With pouch perfusion, lipase, pepsin and acid output was respectively $4.7 \pm 2.1$ units, $2.4 \pm 1.5 \mathrm{mg}$ and $73 \pm 12 \mu \mathrm{Eq}$ over $15 \mathrm{~min}$ (fig 1) which represented 4, 26 and $20 \%$ of the maximal output obtained with pentagastrin stimulation (respectively $120.0 \pm 29.4$ units, $9.0 \pm 4.3 \mathrm{mg}, 364 \pm 57$ $\mu$ Eq per $15 \mathrm{~min})$. The concentrations of lipase, pepsin and acid are given in table 1 . No correlation was obtained between the lipase, acid and pepsin output (table II). Lipase and pepsin output was stable throughout the basal periods, while acid declined ( $40 \%$ over $1 \mathrm{~h}$ ).

Without perfusion, no lipase could be detected. Pepsin output was lower (1.0 \pm $0.5 \mathrm{mg}$ per $15 \mathrm{~min})$; the mean acid output was identical (71 $\pm 7 \mu \mathrm{Eq}$ over $15 \mathrm{~min}$ ).

\section{Meal stimulated secretion}

With pouch perfusion, lipase output rose significantly immediately after the meal and remained high for $75 \mathrm{~min}$ (fig 1), while pepsin output rose slowly and was significantly increased after $1 \mathrm{~h}$. The peaks were respectively 4.1 - and 1.8 -fold the basal level. They reached 16 and $47 \%$ of maximal pentagastrin output. Lipase and pepsin concentrations in the gastric secretion were multiplied by 7.3 and 2.5 -fold respectively (table 1). A positive correlation was observed between the output of lipase and
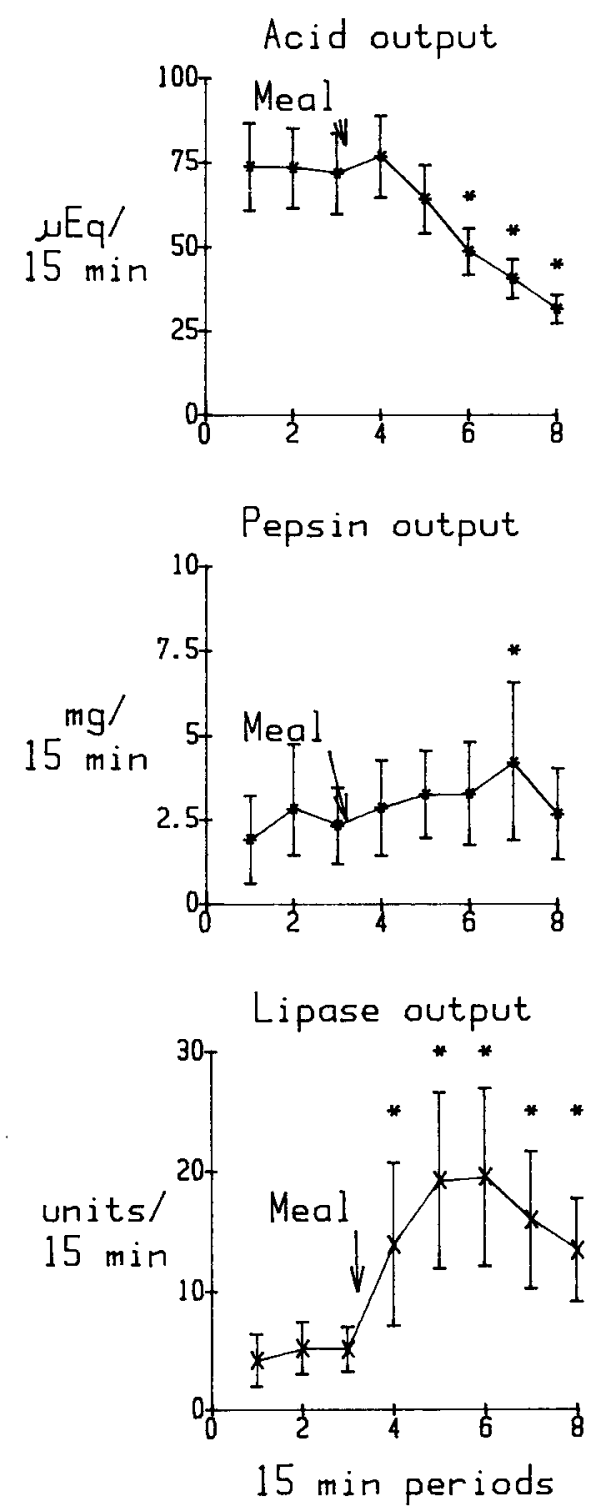

Fig 1. Gastric acid, pepsin and lipase output before and after a meal in rabbits. Gastric secretion was collected by Heidenhain pouch perfusion during basal (period 1 to 3 ) and after a meal, regular diet (periods 5 to 8 ). The means and SEM (vertical lines) are the averaged values of 6 rabbits. "Significantly different from basal output (Wilcoxon test), $P<0.05$. 
Table I. Concentrations in HP secretion (mean \pm SEM) of lipase, pepsin and acid in basal, after meal and pentagastrin stimulation (the number of rabbits is given in parentheses).

\begin{tabular}{llcll}
\hline & $\begin{array}{l}\text { Lipase } \\
\left(U \cdot m t^{+}\right)\end{array}$ & $\begin{array}{l}\text { Pepsin } \\
\left(m g \cdot m r^{-1}\right)\end{array}$ & $\begin{array}{l}\text { Acid } \\
\left(\mu E q \cdot m t^{+}\right)\end{array}$ \\
\hline Basal & $9.2 \pm 5.5$ & $(6)$ & $4.6 \pm 2.3(6)$ & $144 \pm 8(6)$ \\
Meal & $66.8 \pm 35.7^{*}(6)$ & $12.3 \pm 4.5^{*}(6)$ & $159 \pm 8^{*}(6)$ \\
Pentagastrin & $216 \pm 96^{*}$ & $(6)$ & $13.9 \pm 4.7^{*}(6)$ & $166 \pm 6^{*}(6)$ \\
\hline
\end{tabular}

- Significantly different from basal (Wilcoxon test, $P<0.05$ ).

pepsin after the meal (table II). Acid output was not stimulated by the meal (fig 1). Following a transient non-significant rise, a progressive and significant $47 \%$ fall was observed over $1 \mathrm{~h}$ following the meal. This decline was not different from the $40 \%$ drop observed during basal period. The pouch perfusion with $\mathrm{pH} 5.5 \mathrm{NaCl}$ alone without BSA as a buffer led to a 10-fold weaker lipase secretion, while pepsin and acid secretion were unchanged.

Without pouch perfusion, no lipase could be found after the meal in the gastric juice, with a $\mathrm{pH}$ which always remained at $<1$. Feeding induced an increase in pepsin output with a maximum $(4.1 \pm 2.4 \mathrm{mg}$ per $15 \mathrm{~min}$ ) which did not differ from that ob- tained by perfusion (fig 1). Acid output was not increased by feeding and continued to decrease as in the basal condition $45 \pm$ $18 \%)$.

\section{Localization of lipase-secreting cells}

As indicated in table III, lipase-secreting cells were mainly located in the pericardial and fundic areas. The HP was roughly equal to $20 \%$ of the fundic area. The maximal meal-induced lipase output per $15 \mathrm{~min}$ was $=10 \%$ of the total lipase content. Such a comparison is only indicative, since newly-synthesized lipase was not taken into account.

Table II. Correlation ( $r$ ) between basal and meal stimulated lipase, acid and pepsin output of rabbit HP secretion.

\begin{tabular}{llll}
\hline & Acid/Lipase & Acid/Pepsin & Lipase/Pepsin \\
\hline Basal: periods 1-3 & & & \\
$n$ & 24 & 24 & 24 \\
$r$ & -0.313 & -0.016 & 0.060 \\
Meal: periods 4-7 & & & \\
$n$ & 24 & 24 & 24 \\
$r$ & -0.241 & -0.068 & $0.642^{*}$ \\
\hline
\end{tabular}

$n$ : Number of pairs tested; * significant correlation. 
Table III. Lipase activity (expressed in units: $U$ ) in the gastric mucosa of 5 non-fasted rabbits (mean \pm SEM).

\begin{tabular}{lccc}
\hline Area & U/g fresh mucosa & U/mg protein & Total activity (U) \\
\hline Pericardial & $286 \pm 146$ & $5.7 \pm 2.9$ & $410 \pm 226$ \\
Fundus & $391 \pm 192$ & $9.6 \pm 4.8$ & $1083 \pm 497$ \\
Corpus & $63 \pm 28$ & $1.6 \pm 0.7$ & $300 \pm 192$ \\
Antrum & $25 \pm 16$ & $0.8 \pm 0.5$ & $40 \pm 20$ \\
& & & \\
\hline
\end{tabular}

\section{DISCUSSION}

The aim of this study was to determine how gastric lipase is effectively secreted in the rabbit. Our study shows for the first time that feeding stimulates lipase secretion together with pepsin secretion, while acid secretion is not influenced by food intake.

In order to collect gastric juice free of contamination by nutriments, saliva or pancreatic juice, we isolated a gastric pouch at the level of the fundic region of the greater curvature. As rabbit gastric lipase activity is impaired in pure gastric juice with a $\mathrm{pH}<1$ (Perret, 1982) as in the dog (Carriere et al, 1992), the pouch was perfused with an isotonic 5\% BSA solution in $\mathrm{NaCl} 0.9 \%$ at $\mathrm{pH} 5.5$. This value was chosen for 3 reasons. First, the $\mathrm{pH}$ of gastric contents is $>2$ in the rabbit (Marty and Raynaud, 1966) and above the critical $\mathrm{pH}$ for irreversible inactivation of lipase. Secondly, the perfusate is used directly to measure the lipase activity which is maximum at $\mathrm{pH} 5.5$. Thirdly, this $\mathrm{pH}$ also prevents the inactivation of pepsin, which occurs at $\mathrm{pH}>5.5$.

The rise in pepsin and lipase output after the meal is positively correlated, but the differences in the secretion kinetics (lipase peak preceding pepsin peak) and the variations in the ratio between the 2 enzymes are in accordance with the existence of distinct lipase- or pepsin-secreting cells (Moreau et al, 1990a). The rise in HP lipase output is not a result of the decreased acid output which could protect lipase from inactivation since the acid concentration of the HP secretion increases. Moreover, pentagastrin stimulation simultaneously enhanced acid and lipase output.

We find that lipase activity is as high in the fundic as in the pericardial mucosa, in contrast to the immunocytochemical estimations of Moreau et al (1990a). We estimate that $10 \%$ fundic lipase content is secreted in $15 \mathrm{~min}$ at peak ouptut after feeding. As carbamylcholine is a potent stimulus of HP lipase, pepsin and acid secretions in the rabbit (Perret et al, 1993), parasympathetic denervation probably minimizes the secretory response. Comparison of lipase output measured under the same conditions shows a higher postprandial response in the HP rabbit than in the cat. Basal-, cholinergic- and pentagastrin-stimulated secretions are also higher. However, this provides evidence that in the cat the HP mucosa is not as rich in lipase due to the preferential localization of this enzyme near the cardia (Descroix-Vagne et al, 1993; Perret et al, 1993). Our data support the possibility that a potentialization of pancreatic lipase can in fact occur 
in vivo, as has been suggested by in vitro studies (Gargouri et al, 1986b; Bernbäck et al, 1989).

The increase in pepsin output observed during perfusion can arise from a low concentration of topical acid, as has been observed in man (Smith and Torres, 1990) and from osmotic changes, as described in the rat (Puurunen and Westermann, 1978). $A$ reflex arising from the distension of the pouch or the presence of BSA in the perfusate are excluded respectively by the mode of perfusion which avoids such a distension and the similitude of the data obtained with non-protein perfusate. The increase in pepsin induced by feeding was identical with and without pouch perfusion.

We confirm the existence of a high basal acid secretion which is not specific to the rabbit since it has been described in man (Wormsley and Grossman, 1965), the rat (Komarov et al, 1944) and the pig (Meritt and Brooks, 1970), whereas it is null in carnivorous animals (Emas and Grossman, 1967). The high basal secretion observed cannot be attribued to the presence of alimentary residues in the stomach, since stomach emptiness was verified after a 24-h fast with a collar to prevent coecotrophy in anesthetized rabbits before HP surgery. This confirms what has been shown, ie that several $h$ after emptying, the acid output of a fistulated rabbit stomach reached $50 \%$ of the level obtained during pentagastrin stimulation (Redfern et al, 1991).

We have shown, for the first time that feeding does not stimulate acid secretion in the rabbit. The absence of acid stimulation is contrary to what has been observed in the dog (Wasunna et al, 1971) and the cat (Vagne et al, 1982). Several hypotheses might be advanced to explain the lack of acid stimulation by feeding: 1) gastrin is not the major stimulant of acid secretion in the rabbit; 2) gastrin is a major stimulant, but antral acidification does not inhibit gastrin release; 3) the food given to the rabbit does not release enough gastrin; 4) the food also releases acid secretion inhibitors such as somatostatin or cholecystokinin which could be a weak gastrin agonist in the rabbit as in the dog (Johnson and Grossman, 1970) and man (Brooks and Grossman, 1970); 5) cholinergic innervation plays a crucial role in pentagastrinstimulated acid secretion, as has been described by Mulvihill et al, (1989). We previously found (Perret et al, 1993) that the maximally effective dose of pentagastrin for HP acid secretion is much higher than that determined by Redfern et al, (1991) in the innervated stomach: 64 vs $10 \mu \mathrm{g} \cdot \mathrm{kg}^{-1}$, but this is the case for many species. Similar to observations on HP, these authors showed that the high basal acid output is observed in the denervated as well as in the innervated stomach of gastric fistulated rabbits. The increase of acid concentration in meal-stimulated HP secretion rules out the possibility of an increased buffering effect which could lead to an underestimation of acid secretion. The gastric perfusion used to prevent lipase inactivation, which could elicit a local sympathetic reflex which inhibits gastric acid and pepsin in dogs (Magee, 1976), is probably not involved in the acid inhibition since a similar response was obtained without perfusion and acid and pepsin responses were opposite.

In conclusion, the secretion of gastric lipase is immediately and strongly stimulated by a meal in the rabbit. This secretion is positively correlated with that of pepsin which arises a little later, but is not accompanied by a rise in acid secretion. This favors the activity of lipase in the gastric lumen and a synergy between gastric and pancreatic lipase suggested by in vitro experiments. This conclusion cannot be strictly generalized to other mammals in which gastric acid secretion is stimulated by a meal. Isolated rabbit gastric glands or 
cells require a physiological study of the gastric secretion in the isolated pouch to elucidate the mechanism of gastric secretion and the role of gastrointestinal hormones, namely gastrin, somatostatin and cholecystokinin, whose release is not fully understood in the rabbit.

\section{ACKNOWLEDGMENTS}

This study was supported by a grant from Jouveinal Laboratories. The authors gratefully acknowledge the technical assistance of M Gilet and the participation of the following at the Institut Universitaire de Technologie, (Département de Biologie Appliquée, Villeurbanne): B Cottin, T Giordano and $N$ Rentero. Our thanks are also extended to $\mathrm{M} J$ Carew for reviewing the English text.

\section{REFERENCES}

Anson ML (1938) The estimation of pepsin, trypsin, papain and cathepsin with hemoglobin. $J$ Gen Physiol 22, 79-89

Bernbäck S, Bläckberg L, Hernell O (1989) Fatty acids generated by gastric lipase promote human milk triacylglycerol digestion by pancreatic colipase dependent lipase. Biochim Biophys Acta 1001, 286-293

Brooks AM, Grossman MI (1970) Effect of secretin and cholecystokinin on pentagastrin stimulated secretion in man. Gastroenterology 59, 114-119

Carriere F, Raphel V, Moreau $H$, Bernadac A, Devaux MA, Grimaud R, Barrowman JA, Benicourt $C$, Junien $\mathrm{J}$, Laugier $\mathrm{R}$, Verger $\mathrm{R}$ (1992) Dog gastric lipase: stimulation of its secretion in vivo and cytolocalization in mucous pit cells. Gastroenterology 102, 1535-1545

Descroix-Vagne M, Perret JP, Daoud-El Baba M, Bosshard A, Dechelette MA, Gros I, Desvigne A, Rakotomalala H (1993) Variations of gastric lipase secretion in Heidenhain pouch cat. Arch Int Physiol Biochim Biophys, 101, 79-85

El Baba M, Perret JP, Vagne M (1991) Étude des stimulations gastrinique, cholinergique et alimentaire de la sécrétion acide gastrique d'une poche de Heidenhain chez le lapin éveillè. Arch Int Physiol Biochim Biophys 99, 449-453

Emas S, Grossman MI (1967) Comparison of gastric secretion in conscious dogs and cats. Gastroenterology 52, 29-34

Fredrikzon B, Hernell O (1977) Role of feeding on lipase activity in gastric contents. Acta Paediatr Scand 66, 479-484

Gargouri $Y$, Pieroni G, Riviere C, Sauniere JF, Lowe PA, Sarda L, Verger R (1986a) Kinetic assay of human gastric lipase on short and long chain triacylglycerol emulsions. Gastroenterology 91, 919-925

Gargouri Y, Pieroni G, Riviere C, Lowe PA, Sauniere JF, Sarda L, Verger R (1986b) Importance of human gastric lipase for intestinal lipolysis: an in vitro study. Biochem Biophys Acta 879, 419-423

Gregory RA (1958) Gastric secretory responses after portal venous ligation. J Physiol (Lond) $144,123-137$

Johnson LR, Grossman MI (1970) Analysis of inhibition of acid by cholecystokinin in dogs. Am J Physiol 218, 550-554

Komarov SA, Shay $H$, Rayport M, Fels SS (1944) Some observations on gastric secretion in normal rats. Gastroenterology 3, 406413

Lowry OH, Rosebrough NJ, Farr L, Randal RJ (1951) Protein measurement with the Folin phenol reagent. J Biol Chem 193, 265-275

Marty J, Raynaud P (1966) Étude de l'activité organique au niveau du tube digestif chez le lapin. Arch Sci Physiol 20 (4), 515-524

Magee DF (1976) Adrenergic activity and gastric secretion. Proc Soc Exp Biol Med 151, 659662

Meritt AM, Brooks FB (1970) Basal and histamine induced gastric and pepsin secretion in the conscious miniature pig. Gastroenterology $58,801-813$

Moreau $H$, Gargouri $Y$, Lecat $D$, Junien JL, Verger $R$ (1988a) Screening of preduodenal lipases in several mammals. Biochem Biophys Acta 959, 247-252

Moreau H, Sauniere JF, Gargouri Y, Pieroni G, Verger R, Sarles H (1988b) Human gastric lipase: variations induced by gastrointestinal hormones and by pathology. Scand J Gastroenterol 23, 1044-1048 
Moreau H, Bernadac A, Tretout N, Gargouri $Y$, Ferrato F, Verger R (1990a) Immunocytochemical localization of rabbit gastric lipase and pepsinogen. Eur J Cell Biol 51, 165-172

Moreau J, Bouisson $M$, Balas $M$, Ravaud $A$, Stupnik S, Buscail L, Vaysse N, Ribet A (1990b) Gastric lipase in alcoholic pancreatitis. Comparison of secretion profiles following pentagastrin stimulation in normal adults and patients with pancreatic insufficiency. Gastroenterology 99, 175-180

Mulvihill SJ, Pappas TN, Debas HT (1989) Characterization of in vivo secretory responses of rabbit with comparison to dog and rat. Dig Dis Sci 34, 895-904

Perret JP (1982) Lipolyse gastrique chez le lapereau. Origine et importance physiologique de la lipase. J Physiol (Paris) 78, 221-230

Perret JP, Bacques C (1983) Sécrétion de la lipase gastrique du lapereau. Diabète Métab $9, \mathrm{R9}$

Perret JP, Daoud-El Baba M, Rakotomalala $H$, Gros I, Descroix-Vagne M (1993) Cholinergic and pentagastrin stimulation of the gastric secretions of acid, pepsin and lipase in the awake rabbit. Arch Int Physiol Biochim Biophys 101, 79

Puurunen J, Westermann E (1978) Osmotic stimulation of pepsin secretion in the rat.
Naunyn-Schmiedeberg's Arch Pharmacol 304, 63-67

Redfern JS, Lin HJ, Mc Arthur KE, Prince MD, Feldman M (1991) Gastric acid and pepsin hypersecretion in conscious rabbits. $A m J$ Physiol 261, G295-304

Smith JL, Torres EL (1990) Effect of topical acid on pepsinogen secretion in man. Scand $J$ Gastroenterol 25, 372-378

Szafran H, Popiela T, Szafran Z (1971) The effect of 2-deoxy-D-glucose and insulin stimulation on the secretion of gastric lipase. Scand $J$ Gastroenterol 6, 55-58

Szafran Z, Szafran HN, Popiela T, Trompeter G (1978) Coupled secretion of gastric lipase and pepsin in man following pentagastrin stimulation. Digestion 18, 310-318

Vagne M, Konturek SJ, Chayvialle JA (1982) Effect of vasoactive intestinal peptide on gastric secretion in the cat. Gastroenterology 83, 250-255

Wasunna AEO, Buxton BF, Bedi BS, Gillespie IE (1971) Acid responses of denervated fundic Heidenhain pouches to meals compared with those to histamine and pentagastrin. Scand J Gastroenterol 6, 407-410

Wormsley KG, Grossman MI (1965) Maximal histalog test in control subjects and patients with peptic ulcer. Gut 6, 427-435 